\title{
Irrigation suitability evaluation of Zamra irrigation scheme, Abergelle District of Wag-Himra Zone, Amhara Region Ethiopia
}

Workat Sebnie $^{1^{*}} \mathbb{0}$, Enyew Adgo ${ }^{2}$ and Hailu Kendie ${ }^{3}$

\begin{abstract}
Background: Assessment of suitable lands for irrigation is indispensable to plan and implement different programs in a cost-effective approach for sustainable land use planning and efficient utilization of the land. Hence selecting proper land use based on land suitability evaluation will enhance the productivity per unit area and ensures the sustainable use of land resources. Therefore, the research was designed to evaluate the suitability of the soil properties of Zamra irrigation scheme for irrigation purposes.

Method: For this study about 195.16 ha of land were evaluated for irrigation suitablity. Four soil profile pits were opened in the representative site of the scheme based on slope, texture, soil color and soil depth. Soil samples were collected from the soil mapping units for analysis of texture, electrical conductivity, and calcium carbonate content, whereas slope, drainage and soil depth were directly measured at the field. The evaluation was carried out using a parametric evaluation method.

Results: The results of the study revealed that four types of soils were identified namely, Rehodic Nitisol(eutric), Haplic Regosol (eutric) Eutric Regosol, Leptic Regosol (eutric, loamic), and Vertic Cambisol (Hypereutric). The soil texture consists of sandy loam and sandy clay loam at the surface and subsurface soil and the soil depth of study area varied from shallow to very deep. The soil of the scheme was free from salinity and the status of calcium carbonate was at a low level. The slope of the study area was ranged from flat (0-3\%) to slopping (8-15\%). Generally, 80.64 ha (41.32\%) of the scheme was moderately suitable whereas 71.68 ha (36.73\%) of the land was marginally suitable for irrigation. Due to major limiting factors of soil depth and slope about 42.84 ha of the land (21.95\%) were not currently suitable for irrigation.
\end{abstract}

Conclusion: In the study area, the major limitations were slope and soil depth. Therefore, to increase production and productivity of the scheme, land improvement operations are suggested.

Keywords: Suitability, Irrigation, Capability index, Soil type, Scheme

\section{Introduction}

Food security and stability in the world greatly depends on the management of natural resources. Due to the depletion of water resources and an increase in population, the extent of irrigated area per capita is declining

\footnotetext{
*Correspondence: workat85@gmail.com

1 Sekota Dry-Land Agricultural Research Center, P.O. Box 62, Sekota, Ethiopia

Full list of author information is available at the end of the article
}

(Hargreaves and Mekley 1998). However, nearly 40\% of the world's agricultural production comes from irrigated lands (Albaji et al. 2008). To meet food requirements by 2020, Mudima (2002) estimated that food production from irrigated areas will need to increase from $35 \%$ in 1995 to $45 \%$ in 2020 . It has been proposed as a key solution to address the adverse impacts of rainfall, shortfalls, and variability.

Irrigation in Africa has the potential to boost agricultural productivity by at least 50 percent; food production 
on the continent is almost entirely rain-fed (AGRA 2019). Irrigated agriculture is a priority of the agricultural transformation and food security strategy of the Ethiopian Government. Increased availability of irrigation and less dependency on rain-fed agriculture is taken as a means to increase food production and self-sufficiency of the rapidly increasing population of the country (Loiskandl et al. 2008). It is a reliable method of increasing agricultural production and productivity and has greater impacts on solving food security problems in many parts of the country. Realizing its importance for food production, the country has been allocating huge investments for irrigation infrastructure development over the last two decades (Abate 1994).

In Amhara region irrigated agriculture is expanding since recent years. Currently, more than 6,200 small scale irrigation schemes of which $95 \%$ are traditional to exist in the region (Melisew 2012). Interestingly, the irrigation schemes are owned by more than 330,000 households or more than 1.9 million people with an average irrigated land holding of 0.2 ha (Melisew 2012). Furthermore, several new and modern irrigation schemes are under development which will increase the significance of irrigation agriculture in the region. From the new and modern irrigation schemes' constructed in the region Zamra irrigation scheme is the one which is found in Abergelle district of Wag-himra zone. These constructed irrigation schemes' especially in the study area are done without irrigation suitability assessment.

Land suitability assessment plays an important role in maintaining and developing land use on a spatial basis (Diallo et al. 2016; Ahmed 2016). However, the evaluation of irrigation suitability for new as well as the existing irrigation schemes is very important. But, in the study area, such studies are not studied. Therefore, the objective of this study was to evaluate the suitability of Zamra irrigation command area soils for irrigation agriculture.

\section{Materials and methods}

\section{Description of the study area}

The study area Zamra irrigation scheme is located in Abergelle Woreda, Wag-Himra Zone of Amhara Region Ethiopia (Fig. 1). The size of the area is 196.16 ha and the scheme is located $13^{\circ} 01^{\prime} 37.50^{\prime \prime}$ latitude and $38^{\circ} 58^{\prime} 36.50^{\prime \prime}$ longitude with an altitude of 1270 meter above sea level (m.a.s.l). Zamra river is the major source of irrigation water for the scheme and the river flows throughout the year.

The mean annual rainfall of the study area is $622.37 \mathrm{~mm}$ which is an erratic and unevenly distributed over seasons and years (Fig. 2). While the mean minimum and maximum annual air temperatures of the area are 19.19 and $36.08{ }^{\circ} \mathrm{C}$ respectively with the mean annual air temperature of $24.54{ }^{\circ} \mathrm{C}$ (http://gismap.ciat.cgiar .org/MarkSimGCM/\#tabs-2). The farming system is a mixed crop-livestock system in which the livelihood of the people relies on agriculture. Cattle, sheep and goats (Abergelle breed) are the most important livestock reared in the area. The major crops cultivated in the districts are cereals such as sorghum (Sorghum bicolor), Pearl millet (Pennisetum glaucum), seasame (Sesamum indicum L.), teff (Eragrostis tef), Wheat (Triticumae stivum L.) and Cowpea, and Horticultural crops such as Mango (Manifera Indica L), Banana (Mussa Spp), Citrus fruits, pepper (Capsicum Species), Tomato (Solanum Lycopersicum L.), and onion (Alluim cepa L.).

\section{Land suitability evaluation procedure for irrigation}

Four soil mapping units were identified based on surface soil color, slope, texture (by feel method) and soil depth and delineated using ArcGIS 9.1.2 (Fig. 3). Four soil profiles were dug in the representative sites as shown (Fig. 4) of the scheme and described according to FAO (2006) guidelines. The effective soil depth, drainage, and slope were measured directly at the field. The physico-chemical property of the soil were analysed in labratory following the laboratory procedure. The irrigation suitablity evaluation was done based on topography (slope) and soil characteristics (soil texture, depth, salinity, drainage and calcium carbonate content) factors. Parametric evaluation system was used to evualate the land suitability for irrigation using Sys et al. (1991) guideline. The method is based on topography and soil characterstics which are an important environmental factors that influence the irrigation suitablity. In this method, the land is evaluated according to numerical indexes (Table 1). This approach allows calculating the suitability index for irrigation considering the factors that influence the soil suitability. Six parameters such as soil texture, soil depth, calcium carbonates status, electrical conductivity of soil solution, drainage properties, and slope were considered. The capability index for irrigation (Ci) was developed as shown in the equation below:

$$
C i=A \times \frac{B}{100} \times \frac{C}{100} \times \frac{D}{100} \times \frac{E}{100} \times \frac{F}{100}
$$

where Ci: Capability index for irrigation, A: rating of soil texture, B: the rating of soil depth, $\mathrm{C}$ : the rating of $\mathrm{CaCO}_{3}$ status, D: electrical conductivity rating, E: drainage rating, and F: slope rating. After laboratory analysis and directly measured the value at the field for each land mapping unit, the parameters were rated by using Sys et al. (1991) ratting as per the related tables. Irrigation suitability maps of the study area were produced depending on the rating values (Fig. 4). 


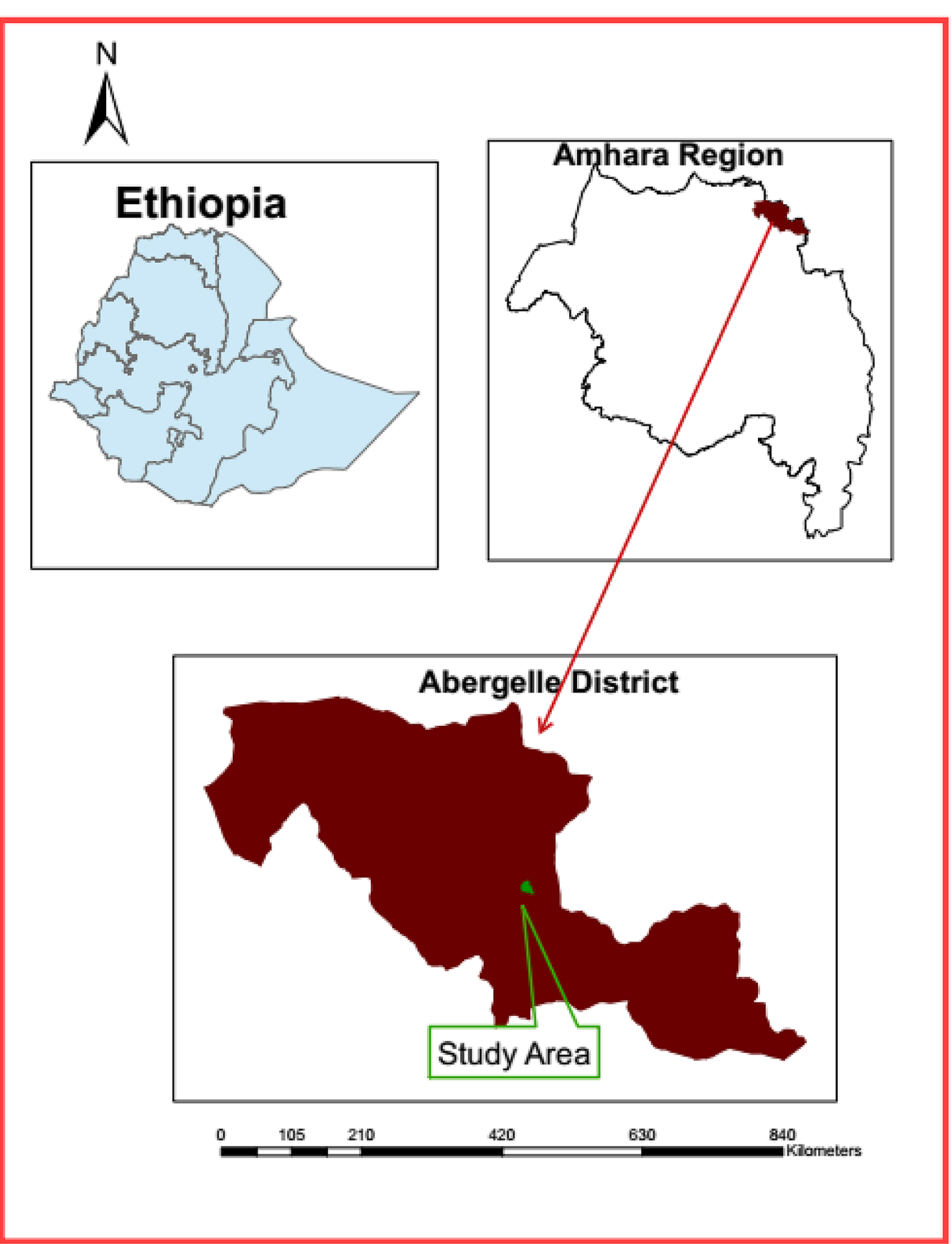

Fig. 1 Map of study area

A procedure used for irrigation suitability map.

\section{Soil sample preparation and Soil analysis}

The collected soil samples were first air-dried, grounded and passed through $2 \mathrm{~mm}$ sieve to undertake the physical and chemical analysis. The particle size distribution of the soils was analyzed by the Bouyoucos hydrometer method (Day 1965). The electrical conductivity was measured by conductivity meter in the soilwater extract (Okalebo et al. 2002). Calcium carbonate content was determined following the acid neutralization method in which the soil carbonate was decomposed by excess standard $\mathrm{HCl}$ solution and back titrated with standard $\mathrm{NaOH}$ after filtering it (Jackson 1970). 


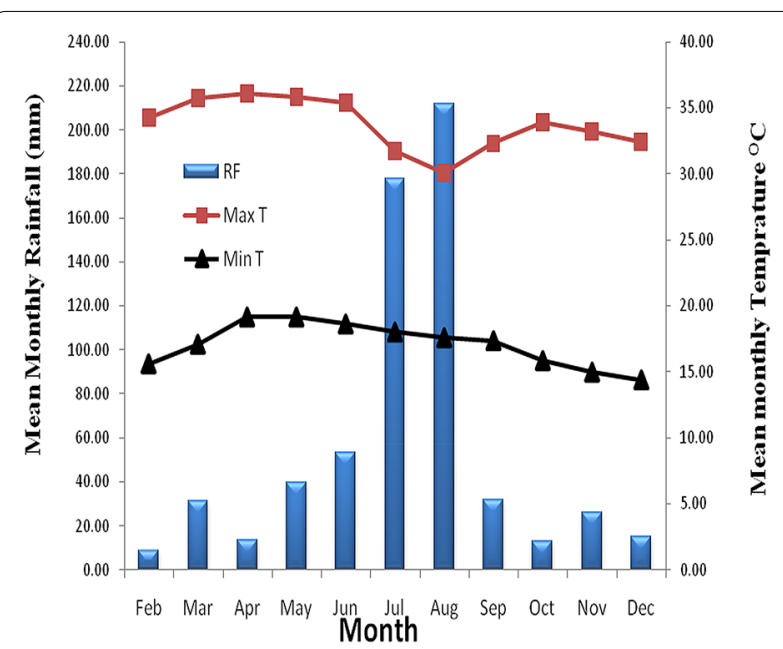

Fig. 2 Mean monthly rainfall, maximum and minimum temperatures

\section{Result and discussion}

\section{Land and soil characteristics of the scheme}

The result of the study areas (Table 2) showed that the soil depths varied from 39 to $178 \mathrm{~cm}$. Except for soil mapping unit 4 Leptic Regosol (eutric, loamic) which is $39 \mathrm{~cm}$ depth, and the other soil mapping units had deep soil $>100 \mathrm{~cm}$ which is good for root growth of the crops. Thus, all soil mapping units except SMU4 Leptic Regosol (eutric, loamic) (the soil depth were rated as $100 \%$ for irrigation suitability. The effective depth of mapping units 1 Rehodic Nitisol(eutric) and SMU2 Vertic Cambisol (Hypereutric) were $>150 \mathrm{~cm}$ which represents very deep soil whereas mapping unit 3 Haplic Regosol (eutric) had deep soil which ranged from 100 to $150 \mathrm{~cm}$. Deep soils are very important to anchor plants nutrient, provide an adequate condition for water, air movement, and growth of roots. Soil depth determines the potential of rooting depth and affects agricultural production.

The textural class of the mapping units of the soil was ranged from sandy clay loam to sandy loam. Soil mapping units 1 Rehodic Nitisol (eutric) and SMU2 Vertic Cambisol (Hypereutric) had a surface textural class of sandy clay loam whereas soil mapping units 3 Haplic Regosol (eutric) \& 4 Leptic Regosol (eutric, loamic) had sandy loam textural class. Soil mapping units 1 Rehodic Nitisol (eutric) and SMU2 Vertic Cambisol (Hypereutric) were rated as $95 \%$ suitable whereas land mapping units 3 and 4 as $75 \%$ suitable for irrigation (Table 2). The slope of a given area plays an important role in agricultural production and productivity. The slope of the study area ranged from flat $(0-3 \%)$ to sloping $(8-15 \%)$. The soil mapping unit 2 Vertic Cambisol (Hypereutric) had a flat $(0-3 \%)$ slope which is suitable for agriculture production whereas soil mapping unit 1 Rehodic Nitisol (eutric) (3-5\%) and soil mapping unit 3 Haplic Regosol (eutric) (5-8\%) where the indicated slope is less suitable for agriculture than mapping unit 2 Vertic Cambisol (Hypereutric). According to Sys et al. (1991) landscapes with $1-3 \%$ slope are rated $95 \%$ suitable, $3-5 \%$ slope as $90 \%$ suitable, $5-8 \%$ rated $80 \%$ suitable, and $8-16 \%$ slope rated as $70 \%$ suitable for none terraced slopes. According to Sys et al. (1991), soil drainage of a specified area can be divided into five classes. These are well-drained, moderately drained, imperfectly drained, poorly drained and very poorly drained. The study area soils had a welldrained and moderately drain in all mapping units. Soil mapping units 1 Rehodic Nitisol (eutric) and SMU2 Vertic Cambisol (Hypereutric) were moderately drained whereas soil mapping units 3 Haplic Regosol (eutric) and SMU4 Leptic Regosol (eutric, loamic) were well drained and rated for irrigation as $90 \%$ and $95 \%$ suitable, respectively. The calcium carbonate status influences the soilwater relationship of the soil and its available nutrient for plant growth (Sys et al. 1991). The calcium carbonate content of the soil in the study site ranges from $0.3-10 \%$ which had an irrigation rating value of $95 \%$. The salt content of the soil was considered as suitable for irrigation and rated 100 for all mapping units.

\section{Land suitability evaluation of the irrigation scheme}

The result revealed that soil mapping unit 1 Rehodic Nitisol(eutric) and Vertic Cambisol (Hypereutric) soil mapping unit 2 had above $60 \%$ of capability index which is moderately suitable (S2), whereas soil mapping unit 3 Haplic Regosol (eutric) was slightly suitability (S3) with $47.38 \%$ of capability index and soil mapping unit 4 Leptic Regosol (eutric, loamic) had 32.49\% capability index which is currently not suitable (N1) for irrigation (Table 3). As shown in Table 3, there is no an area classified as highly suitable (S1) or permanently non-suitable for irrigation (N2) (Fig. 5).

The largest area of the scheme (80.64 ha) is considered as being moderately suitable land for irrigation due to the limitation of a moderate slope, texture, and drainage. Soil texture affects permeability, water holding capacity, and infiltration of soil. There was no any permanently nonsuitable land for irrigation in the study area. The largest portion of the scheme were moderately suitable for irrigation this might be due to the moderate slope, texture, and drainage limitations. The current study is similar with Sulieman et al. (2015) who reported that the largest area of their study was found moderately suitable for irrigation due to limitation of texture and drainage. Similarly Kebede and Ademe (2016) reported that the largest portion of the land was moderately suitable for surface irrigation due to slope factor. The marginally suitable land was covered by about 71.68 ha which was due to limiting 


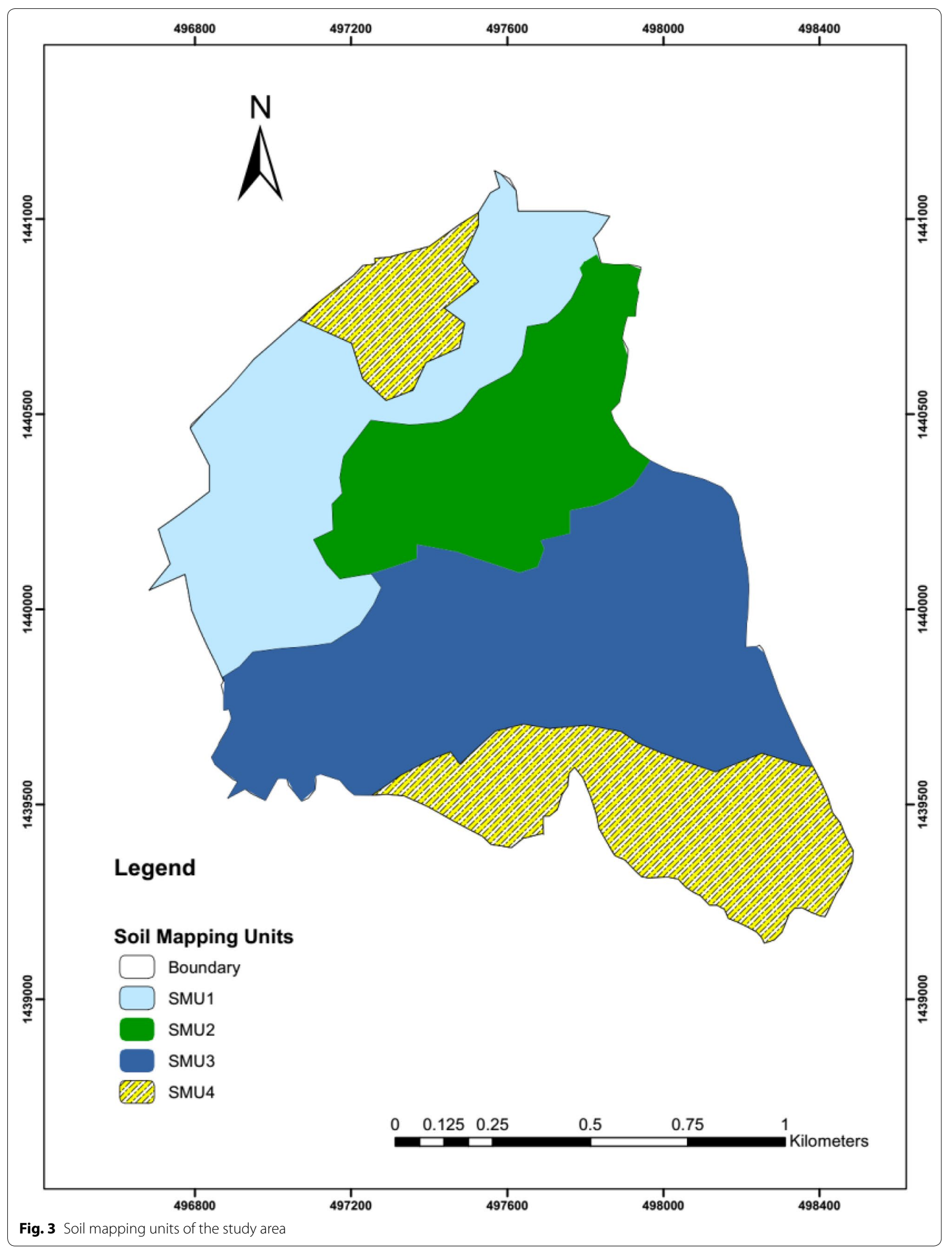




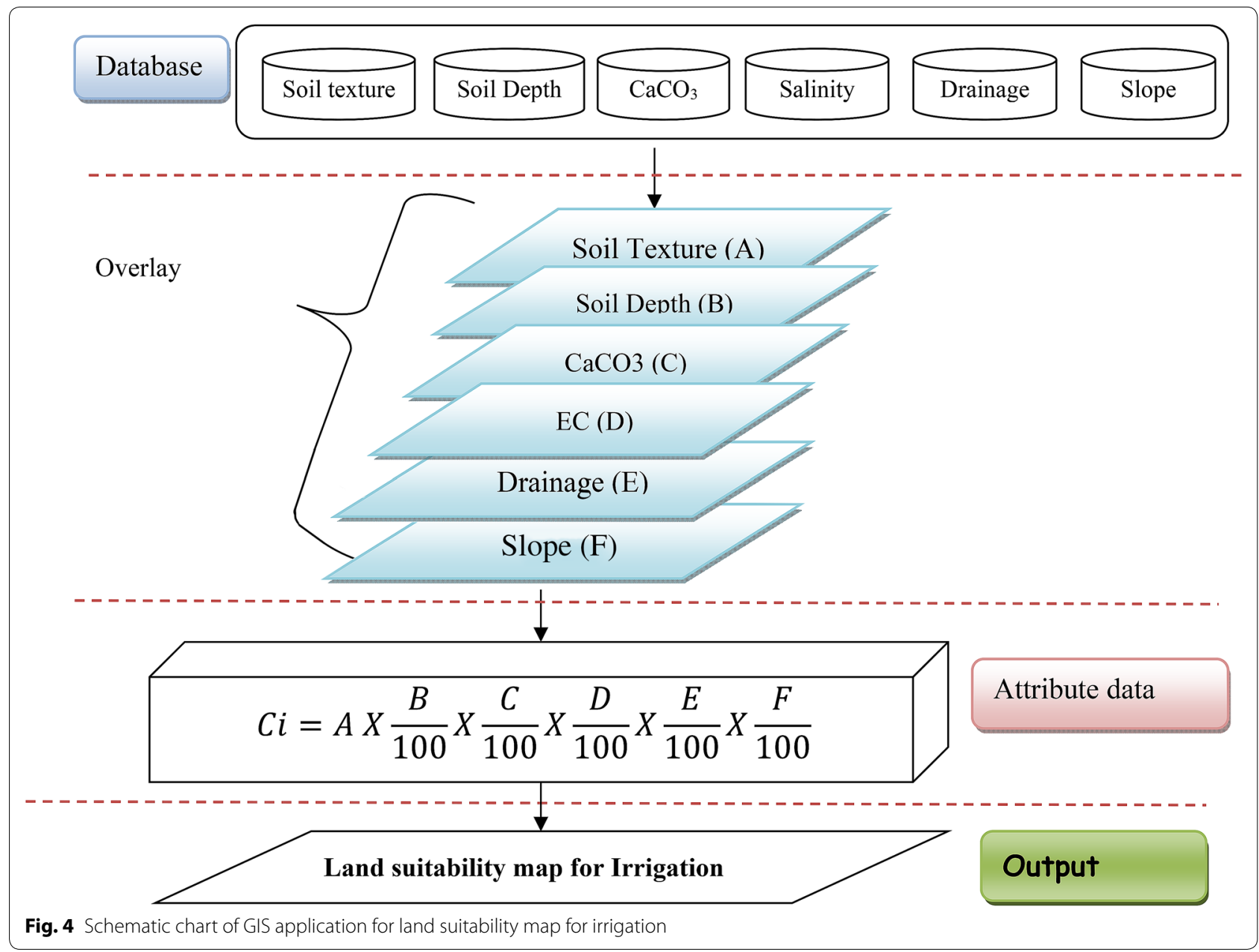

Table 1 Suitability classes for the irrigation capability indices $(\mathbf{C i})$

\begin{tabular}{lll}
\hline Symbol & Definition & Capability index \\
\hline S1 & Highly suitable & $>80$ \\
S2 & Moderately suitable & $60-80$ \\
S3 & Marginally suitable & $45-60$ \\
N1 & Currently not suitable & $30-45$ \\
N2 & Permanently not suitable & $<30$ \\
\hline
\end{tabular}

Table $3 \mathrm{Ci}$ values and suitability classes of each mapping units for irrigation

\begin{tabular}{|c|c|c|c|c|}
\hline \multirow{2}{*}{$\begin{array}{l}\text { Land } \\
\text { mapping } \\
\text { unit }\end{array}$} & \multicolumn{2}{|l|}{ Area } & \multirow[t]{2}{*}{ Capability index } & \multirow[t]{2}{*}{ Suitability class } \\
\hline & ha & $\%$ & & \\
\hline SMU1 & 45.69 & 23.41 & 73.10 & Moderately suitable \\
\hline SMU2 & 34.95 & 17.91 & 77.27 & Moderately Suitable \\
\hline SMU3 & 71.68 & 36.73 & 47.38 & Marginally suitable \\
\hline SMU4 & 42.84 & 21.95 & 32.49 & Currently not suitably \\
\hline
\end{tabular}

SMU soil mapping unit

Table 2 Land and soil characteristics rating for irrigation of the land units

\begin{tabular}{|c|c|c|c|c|c|c|c|c|c|c|c|}
\hline \multirow{3}{*}{$\begin{array}{l}\text { Land } \\
\text { mapping unit }\end{array}$} & \multirow{2}{*}{\multicolumn{2}{|c|}{$\frac{\mathrm{A}}{\text { Texture }}$}} & \multirow{2}{*}{\multicolumn{2}{|c|}{$\frac{\text { B }}{\text { Depth }}$}} & \multirow{2}{*}{\multicolumn{2}{|c|}{$\frac{\mathrm{C}}{\mathrm{CaCO}_{3}}$}} & \multirow{3}{*}{$\begin{array}{l}\text { D } \\
\text { Drainage }\end{array}$} & \multirow{2}{*}{\multicolumn{2}{|c|}{$\frac{E}{E C}$}} & \multirow{2}{*}{\multicolumn{2}{|c|}{$\begin{array}{l}\text { F } \\
\text { Slope }\end{array}$}} \\
\hline & & & & & & & & & & & \\
\hline & Rating & Class & Rating & $\mathrm{Cm}$ & Rating & $\%$ & & Rating & $\mathrm{dsm}^{-1}$ & Rating & $\%$ \\
\hline SMU1 & 95 & $\mathrm{SCL}$ & 100 & 178 & 95 & 0.5 & 90 & 100 & 0.11 & 90 & $(3-5)$ \\
\hline SMU2 & 95 & $\mathrm{SCL}$ & 100 & 167 & 95 & 2 & 90 & 100 & 0.12 & 95 & $(0-3)$ \\
\hline SMU3 & 75 & SL & 100 & 134 & 95 & 0.6 & 95 & 100 & 0.10 & 70 & $(5-8)$ \\
\hline SMU4 & 75 & $S L$ & 60 & 39 & 95 & 3 & 95 & 100 & 0.06 & 80 & $(8-15)$ \\
\hline
\end{tabular}

SMU soil mapping unit, SCL sand caly loam, sand loam 


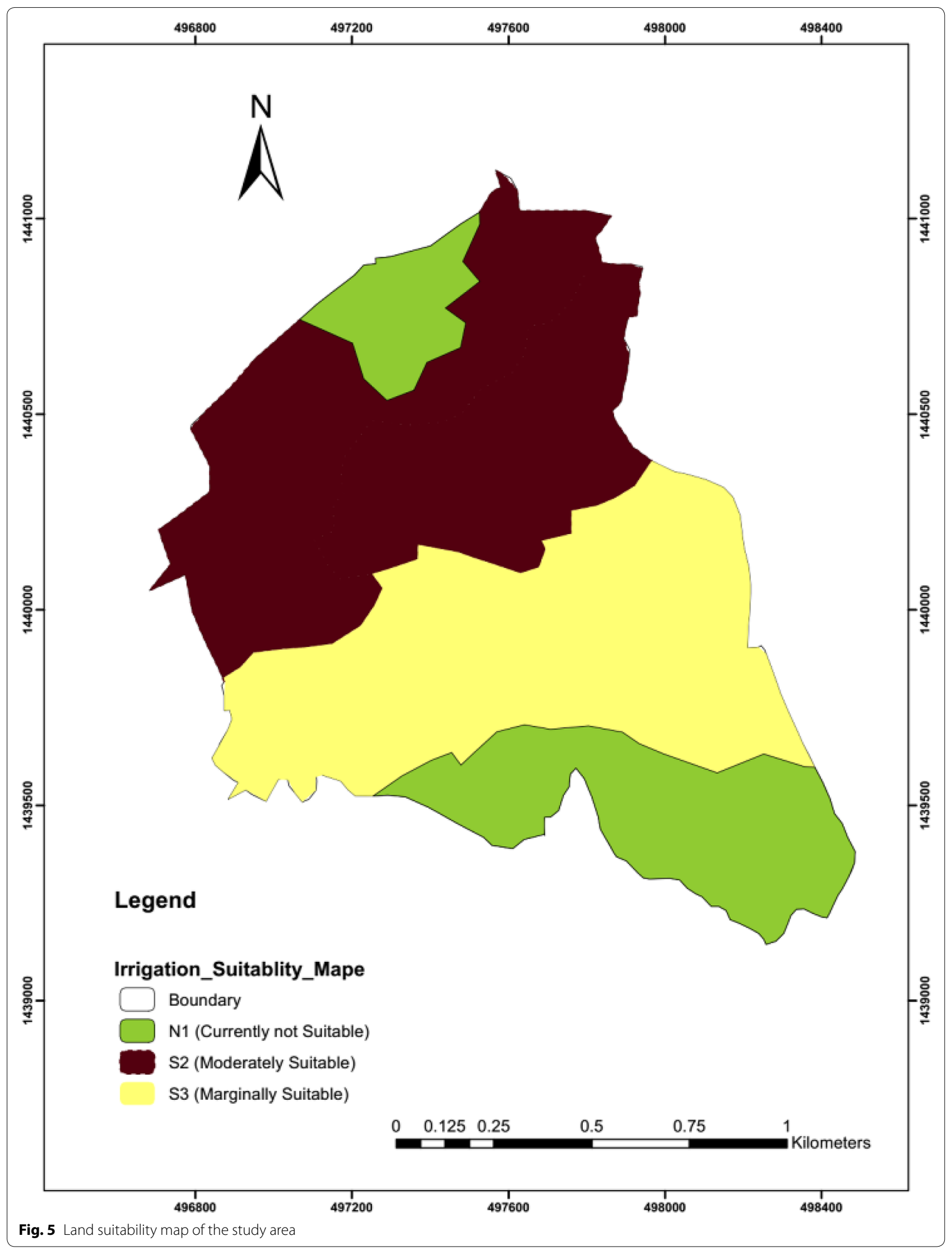


factors of texture, slope, and drainage. Due to slope, texture, depth and drainage land characteristics factor about 114.52 ha of land is marginally and currently non suitable for irrigation in the scheme. Different researches conducted in irrigation suitability evaluation confirmed that major limiting factor for irrigation suitability are slope, depth, texture and drainage. Research conducted by Yitbarek et al. (2016), in western Ethiopia showed that due to limiting factors of soil depth and texture the land was marginally suitable for irrigation. Similarly, research conducted in Dejen areas of Ethiopia by Mehari and Alebachew (2013) comfirmed that about 341 ha of land were marginally and currently non suitable for irrigation due to limting factors of slope, soil depth, and texture.

Depth do not influence the suitability of soil maping unit 1 Rehodic Nitisol (eutric) and SMU2 Vertic Cambisol (Hypereutric) whatsoever. Currently non-suitable land was observed in the scheme due to the physical limitations of soil depth rated (60\%), texture rated (75\%), and slope rated (80\%). It covers about 42.84 ha of land. There was no permanently non-suitable land in the irrigation command area. Salinity was not considered as a limiting factor in the study area. There was no highly suitable land for irrigation in the study area. Similar result was reported by Mehari and Alebachew (2013) and Sulieman et al. (2015) who confirmed that they did not found highly suitable land for irrigation.

\section{Conclusion and recommendation}

Irrigation suitability evaluation using the parametric method is very important to identify the irrigable and non-irrigable lands. The method is based on the topography, physical, and chemical properties of the soil without considering the social and economic constraints. Result obtained from the study confirmed that the soils are moderately suitable, marginally suitable, and currently not suitable for irrigation. Vertic Cambisol (Hypereutric) and Rehodic Nitisol (eutric) are moderately suitable for irrigation while Haplic Regosol (eutric) is marginally suitable and Leptic Regosol (eutric, loamic) is not currently suitable for irrigation due to major limiting factors of depth and slope. Generally, about 80.64 ha or $41.32 \%$ of irrigated land is moderately suitable, about 71.68 ha or $36.73 \%$ of the land is marginally suitable and about 42.84 ha or $21.95 \%$ of the scheme is currently not suitable for irrigation. It could be recommended that, further, studies should be carried out on water quality, water requirements, irrigation interval, suitability evaluation for different horticultural crops to maximize the water productivity and production of the study area.

\section{Acknowledgements}

We would like to thank Amhara Agricultural Research Institute and Sekota DryLand Agriculturaral Research Center for supporting the research fund.

\section{Authors' contributions}

WS did the experimental work, processed the data and wrote the first draft of the manuscript. EA and HK. supervised and revised the manuscript. All authors read and approved the final manuscript.

\section{Funding}

Not applicable.

\section{Availability of data and materials}

The data used to support the findings of this study are available from the corresponding author upon request.

\section{Ethics approval and consent to participate}

Not applicable.

\section{Consent for publication \\ Not applicable.}

\section{Competing interests}

The authors declare that there are no conflicts of interest regarding this article.

\section{Author details}

${ }^{1}$ Sekota Dry-Land Agricultural Research Center, P.O. Box 62, Sekota, Ethiopia. ${ }^{2}$ College of Agriculture and Environmental Sciences, Bahir Dar University, P.O. Box 1289, Bahir Dar, Ethiopia. ${ }^{3}$ Amhara Agricultural Research Institute, P.O. Box 527, Bahir Dar, Ethiopia.

Received: 30 August 2020 Accepted: 13 November 2020

Published online: 03 December 2020

\section{References}

Abate Z (1994) Water resources development in Ethiopia: an evaluation of present experience and future planning concepts. Ithaca Press, London Mahari A, Alebachew A, Markos D (2013) Land suitability evaluation for irrigation in Dejen District, Ethiopia.

Ahmed MAE (2016) Land evaluation of Gharb El-Mawhob Area, El Dakhla Oasis, New Valley, Egypt (Doctoral dissertation. Thesis, Faculty of Agriculture, Assiut University, Assiut, Egypt), M. Sc

Albaji M, Landi A, Boroomand Nasab S, Moravej K (2008) Land suitability evaluation for surface and drip irrigation in Shavoor Plain Iran. J Appl Sci 8(4):654-659

AGRA (2019) Irrigation Doubles African Food Production https://agra.org/irrig ation-doubles-african-food-production/accessed.March 2019.

Day P (1965) Hydrometer method of particle size analysis. Methods Soil Anal Agronomy 9:562-566

FAO (1995) Irrigation in Africa in figures/Lirrigation en Afrique en chiffres. FAO Water Report 7. Rome

FAO (2006) Guidelines for soil description. Food and Agriculture Organization of the United Nations, Rome

Hargreaves HG, Mekley GP (1998) Irrigation fundamentals. Water Resource Publication, LLC, p 200

Jackson ML (1973) Soil Chemical Analysis, New Delhi. Prentice Hall of India Pvt, Ltd

Kebede T, Ademe Y (2016) Evaluating land suitability for irrigation purpose in Abaya district, Borena zone Ethiopia. Afr J Agric Res 11(46):4754-4761

Mudima K (2002) Socio-economic impact of smallholder irrigation development in Zimbabwe: a case study of five successful irrigation schemes. In: Private Irrigation in sub-Saharan Africa; Proceedings of Regional Seminar on Private Sector Participation and Irrigation Expansion in sub-Saharan Africa, pp. 21-30.

Loiskandl W, Ruffeis D, Schönerklee M, Spendlingwimmer R, Awulachew SB, Boelee $E$ (2008) Case study review of investigated irrigation projects in Ethiopia (No. 614-2016-40876)

Mahari A, Alebachew A (2013) Land suitability evaluation for irrigation in Dejen District Ethiopia. Int J Sci Res 3:99 
MarkSim ${ }^{\circledR}$ Weather file generator 2018. http://gismap.ciat.cgiar.org/MarkS imGCM/\#tabs-2. Accessed 12 Dec 2018.

Melisew M (2012) Organization and Management of Irrigation Schemes in Eastern Amhara, Ethiopia: In Case of Sanka Traditional and Golina Modern Irrigation Schemes (Doctoral dissertation, Cornell University).

Diallo MD, Wood SA, Diallo A, Mahatma-Saleh M, Ndiaye O, Tine AK et al (2016) Soil suitability for the production of rice, groundnut, and cassava in the peri-urban Niayes zone. Senegal Soil Tillage Res 155:412-420

Okalebo JR, Gathua KW, Womer PL (2002) Laboratory methods of soil and plant analysis: A working manual, 2nd (Edn.). TSBF-CIAT and SACRED Africa, Nairobi, Kenya

Sulieman MM, Ibrahim IS, Elfaki J (2015) Evaluation of Land Suitability for Agriculture under Irrigation at Khartoum North Sudan. Int J Sci Res Publ 5(9):99
Sys C, Van Ranst E, Debaveye J (1991) Land Evaluation. Part 1: Principles in Land Evaluation and Crop Production Calculations; Part 2: Methods in Land Evaluation; Part 3: Crop Requirements (in press). Agricultural Publications no. 7., General Administration for Development Cooperation, Brussels

Yitbarek T, Kibret K, Beyene S (2017) Physical land suitability evaluation for irrigation in the lower alwero river area of Abobo, Western Ethiopia. Am J Agric For 5(3):60-64

\section{Publisher's Note}

Springer Nature remains neutral with regard to jurisdictional claims in published maps and institutional affiliations.

\section{Submit your manuscript to a SpringerOpen ${ }^{\circ}$ journal and benefit from:}

- Convenient online submission

- Rigorous peer review

- Open access: articles freely available online

- High visibility within the field

Retaining the copyright to your article

Submit your next manuscript at $\boldsymbol{\nabla}$ springeropen.com 